\title{
Bioremoval of Chromium (Iii) from Model Tanning Effluent by Novel Microbial IsolatE
}

\author{
Abhilash Divya G Nair*, Kirtal Hansdah, B. Dhal, K. D. Mehta, B. D. Pandey \\ CSIR-National Metallurgical Laboratory (CSIR), 831007, Jamshedpur \\ biometnml@gmail.com
}

\begin{abstract}
Tanneries have always been under the scanner of Pollution Control Boards with respect to the amount of effluents and solid wastes that they generate. Wastewater from tanneries usually contains high concentration of chlorides, sodium sulfide, aliphatic sulfonates, sulfates and several other organic components including fatty acids, proteins and soluble carbohydrates. Chromium is present in the wastewater because of its use as a tanning agent in the form of basic chromium sulfate. In this paper, our efforts on isolation of Penicillium sp. from a tannery effluent sample and its use as a sorbent to remove $\mathrm{Cr}$ (III) from a model solution are described. Various parameters such as $\mathrm{pH}$, temperature, biomass dose, particle size of the biosorbent and initial metal ion concentration have been optimized. With a model solution of 100ppm Cr(III), about $84 \%$ sorption is achieved with $1 \%(\mathrm{w} / \mathrm{v})$ biomass of $<150 \mu \mathrm{m}$ size Penicillium species at $4.0 \mathrm{pH}$ and $35^{\circ} \mathrm{C}$ temperature.
\end{abstract}

Keywords Tannery Effluent, Chromium, Ground Water Pollution, Toxicity, Penicillium Species

\section{Introduction}

Since the invention of chrome tanning in 1858 by Knapp, the leather industry has undergone a makeover change. Around $90 \%$ of the leather produced globally is by chrome tanning, let alone, in India $80 \%$ of the leathers are produced by chrome tanning[1,2]. Large amounts of $\mathrm{Cr}$ (III) can also be hazardous to health and its natural oxidation to hexavalent state further complicates the issue. Hence, stringent discharge limits have been specified for chromium into inland water (0.1-5.0 mg/L); sewer (1-10 mg/L); and surface water $(1.0 \mathrm{mg} / \mathrm{L})[3,4]$. In order to bring down the level of chromium in the effluents to an acceptable limit, various physicochemical methods such as ion-exchange, precipitation and reverse osmosis are employed but these methods have certain constraints such as incomplete metal removal, high reagent consumption, and generation of toxic sludge[5]. Amongst the alternate options, use of biotechnological approach viz., biosorption is finding acceptability which involves the utilisation of microorganisms such as algae, fungi, bacteria as biosorbents for the removal of metal ions. The technological merit of this process lies in the ability of negatively charged cell surface of microorganisms to bind the metal cations. The interaction of metallic ions with microbe cell surface depends not only on the nature of biosorbent used but also on the solution

* Corresponding author:

biometnml@gmail.com (Abhilash Divya G Nair) Published online at http://journal.sapub.org/ijmee

Copyright (C) 2012 Scientific \& Academic Publishing. All Rights Reserved chemistry of the metal to be removed[6,7]. The stability diagram of chromium in water[8,9] at $25 \mathrm{oC}$ is given in Fig. 1, which shows the presence of different species at varying $\mathrm{pH}$ and potential.

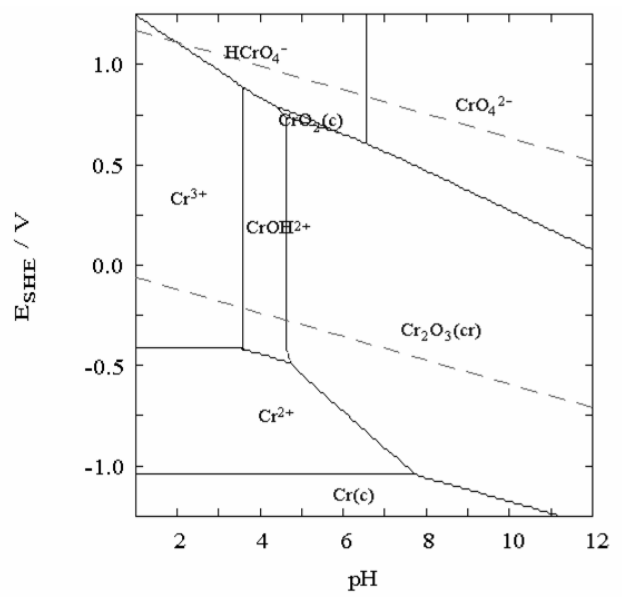

Figure 1. Pourbaix Diagram of Chromium in water at $25{ }^{\circ} \mathrm{C}$ [Concentration $=1 \mathrm{M}]$

The most stable valence state of chromium, in aqueous media is the trivalent species. Chromium exists in its trivalent form predominantly at lower $\mathrm{pH}$. As the $\mathrm{pH}$ rises, $\mathrm{Cr}(\mathrm{III})$ precipitates as $\mathrm{Cr}(\mathrm{OH})_{3}[8,9]$.

In the present investigation, a fungus, Penicillium sp. was isolated from a tannery effluent sample and was used for biosorption of $\mathrm{Cr}$ (III) from model tanning effluent.

\section{Materials and Methods}




\subsection{Microbial Isolate}

Penicillium sp. was isolated from a tannery effluent sample procured from Chennai and was cultivated in Czapek Dox broth[Composition: Sucrose: $30 \mathrm{~g} / \mathrm{L}$; Sodium nitrate: $3.0 \mathrm{~g} / \mathrm{L} ;$ Di-potassium phosphate: $1.0 \mathrm{~g} / \mathrm{L}$; Magnesium sulphate: $0.50 \mathrm{~g} / \mathrm{L}$; Potassium chloride: $0.50 \mathrm{~g} / \mathrm{L}$; Ferrous sulphate: $0.01 \mathrm{~g} / \mathrm{L}$ ] at $35^{\circ} \mathrm{C}$ and $\mathrm{pH} 2.5$ in an orbital shaker[10]. Citric acid produced by the fungus was estimated on a daily basis, by titrating $10 \mathrm{~mL}$ of broth culture without the fungal pellets against $0.5 \mathrm{~N} \mathrm{NaOH}$ using bromothymol blue as indicator. The pure isolate was studied for its growth characteristics in absence of various nutrients of the artificial media. The purified isolate was preserved as culture slants for biochemical and molecular characterization.

Fully grown culture was filtered using Whatman filter paper No.1 and rinsed thoroughly with de-ionised water for 5-6 times and dried at room temperature to a constant weight lessening moisture content. The dried biomass was passed through a sieve to get particle size of $<150 \mu \mathrm{m}$.

\subsection{Model Tanning Effluent Solution}

A model tanning effluent[11] (MTE)[Composition: $\mathrm{CaCl}_{2}: 0.319 \mathrm{~g} / \mathrm{L} ; \mathrm{MgCl}_{2} .6 \mathrm{H}_{2} \mathrm{O}: 0.962 \mathrm{~g} / \mathrm{L} ; \mathrm{Na}_{2} \mathrm{~S}: 0.234 \mathrm{~g} / \mathrm{L}$; $\left.\mathrm{Na}_{2} \mathrm{SO}_{4} \cdot 10 \mathrm{H}_{2} \mathrm{O}: 6.205 \mathrm{~g} / \mathrm{L} ; \mathrm{NaCl}: 1.119 \mathrm{~g} / \mathrm{L}\right]$ was prepared with $200 \mathrm{ppm} \mathrm{Cr}(\mathrm{III})$ using $\mathrm{CrCl}_{3} \cdot 6 \mathrm{H}_{2} \mathrm{O}$ as source. All chemicals used were of AR grade. The $\mathrm{pH}$ of the solution was maintained at 4.0, unless stated otherwise, by using $10 \mathrm{~N}$ $\mathrm{H}_{2} \mathrm{SO}_{4}$ and $2 \mathrm{~N} \mathrm{NaOH}$.

\subsection{Biosorption Experiments}

The factors that affect the biosorption rate and uptake capacity of the biosorbent were examined in a batch mode. Unless stated otherwise, all experiments were carried out with $1 \%(\mathrm{w} / \mathrm{v})$ biomass having particle size $<150 \mu \mathrm{m}$ in 250 $\mathrm{ml}$ Erlenmeyer flasks containing $100 \mathrm{~mL}$ of MTE with $100 \mathrm{ppm} \mathrm{Cr}$ (III) on a horizontal shaker, operating at 100rpm set at $35^{\circ} \mathrm{C}$. The effect of $\mathrm{pH}$, temperature, biosorbent dose, particle size of the sorbent and effect of initial metal ion concentration on removal of $\mathrm{Cr}$ (III) ions was examined. Samples were withdrawn at periodic intervals. Concentration of $\mathrm{Cr}(\mathrm{III})$ ions was estimated by AAS. The percent adsorption (\%) and distribution constant $\left(\mathrm{K}_{\mathrm{d}}\right)$ were calculated by:

$$
\text { Adsorption (\%) }=\frac{C_{i}-C_{f}}{C_{i}} \times 100
$$

where $\mathrm{C}_{\mathrm{i}}$ and $\mathrm{C}_{\mathrm{f}}$ are the concentration of the metal ions in the initial and final solutions $(\mathrm{mg} / \mathrm{L})$, respectively:

$$
K_{d}=\frac{\text { Amount of metal in adsorbent }}{\text { Amount of metal in solution }} \times \frac{\mathrm{V}}{\mathrm{m}}
$$

where $\mathrm{V}$ is the volume of the solution $(\mathrm{mL}), \mathrm{m}$ is the weight of the adsorbent $(\mathrm{g})$.

\section{Results and Discussions}

\subsection{Growth Characteristics of Penicillium Species}

Change in morphology of the fungus with respect to variation in nutrient sources showed that Penicillium could grow in the absence of potassium chloride (Table 1).

\begin{tabular}{|c|c|c|}
\hline $\begin{array}{l}\text { Media } \\
\text { Comp. } \\
\text { absent }\end{array}$ & Days & Observations \\
\hline \multirow{4}{*}{ Sucrose } & 2 & Growth of conidia, thin mycelia \\
\hline & 4 & Thin mycelia, less vacoules \\
\hline & 6 & Less growing stage, little branching \\
\hline & 8 & Degraded mycelia, hyphae budded \\
\hline \multirow{4}{*}{$\mathrm{NaNO}_{3}$} & 2 & Bud formed, growth started \\
\hline & 4 & Slow growth compare to normal \\
\hline & 6 & Loose mycelium, less spores \\
\hline & 8 & Scattered budded hyphae \\
\hline \multirow{4}{*}{$\mathrm{K}_{2} \mathrm{HPO}_{4}$} & 2 & Conidiophores with thick mycelia \\
\hline & 4 & Less growth, short filamentous \\
\hline & 6 & Rapidly growing mycelia \\
\hline & 8 & Weak forming mycelia wall \\
\hline \multirow{4}{*}{$\mathrm{MgSO}_{4}$} & 2 & Growing stage appeared \\
\hline & 4 & Well developed mycelia with spores \\
\hline & 6 & Budded hyphae at the terminal \\
\hline & 8 & Vertical growth in budded hyphae \\
\hline \multirow{4}{*}{$\mathrm{KCl}$} & 2 & No branching, vacuole present \\
\hline & 4 & Bifurcate hyphae, growth appeared \\
\hline & 6 & Conidiophores present, spore present \\
\hline & 8 & Buds in pre proliferation stage. \\
\hline
\end{tabular}

Table 1. Influence of media components of CZB on fungal growth

Citric acid is a metabolite produced by the fungus during its growth stage. At the end of 8 days, amount of citric acid produced by the fungus was found to be $4.02 \mathrm{~g} / \mathrm{L}$ correlating it to the full growth of fungal cells.

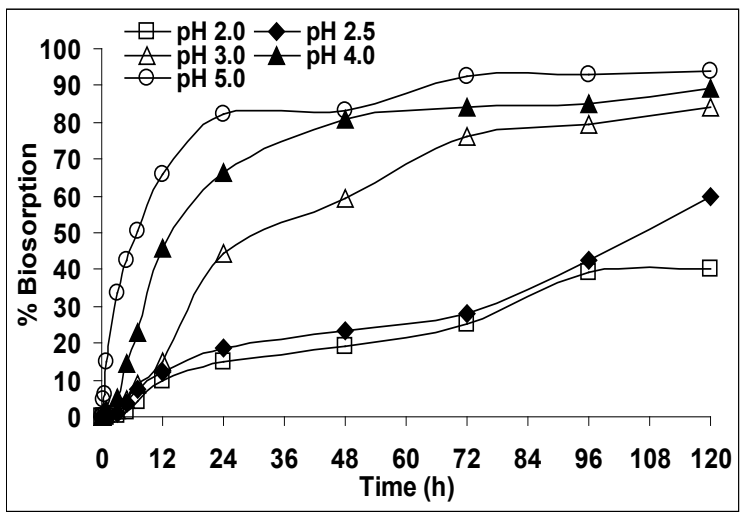

Figure 2. Effect of $\mathrm{pH}$ on $\mathrm{Cr}(\mathrm{III})$ biosorption at $35^{\circ} \mathrm{C}, 1 \%(\mathrm{w} / \mathrm{v})$ biomass of $<150 \mu \mathrm{m}$ size

\subsection{Effect of $\mathrm{pH}$}

$\mathrm{pH}$ is a critical parameter for biosorption studies as it not only influences the speciation of the metal ion in solution but also can change the state of the active binding sites, which are usually acidic[7]. The effect of $\mathrm{pH}$ on $\mathrm{Cr}$ (III) biosorption was studied in the range 2.0- 5.0. As shown in Figure.2, biosorption efficiency was low at $\mathrm{pH} 2.0$ because of competition for sorption sites between the highly available hydrogen ions and metal ions. The sorption capacity increased gradually with an increase in $\mathrm{pH}[12]$. Maximum 
biosorption of $84 \%$ and $93 \%$ was obtained respectively at $\mathrm{pH}$ 4.0 and 5.0. As at $\mathrm{pH}$ above $4.5, \mathrm{Cr}(\mathrm{III})$ is likely to be precipitated as $\mathrm{Cr}(\mathrm{OH})_{3}$, the value at $\mathrm{pH} 4.0$ may be taken as the optimum[8,9].

\subsection{Effect of Initial Metal Ion Concentration}

The results on variation of $\mathrm{Cr}$ (III) concentration are shown in Fig.3.A decrease in biosorption beyond 100 ppm Cr(III) in feed was observed.

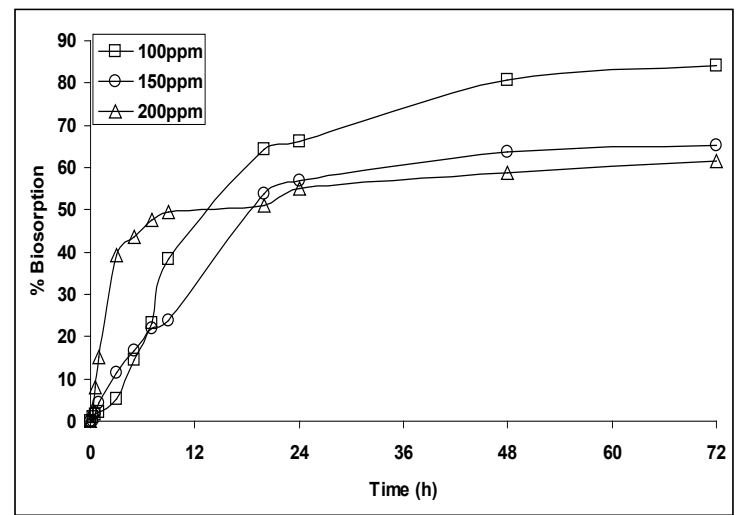

Figure 3. Effect of initial metal ion concentration on $\mathrm{Cr}$ (III) biosorption at $\mathrm{pH} 4.0,35^{\circ} \mathrm{C}, 1 \%(\mathrm{w} / \mathrm{v})$ biomass of $<150 \mu \mathrm{m}$ size

\subsection{Effect of Particle Size}

Four different particle sized biomass of $>150 \mu \mathrm{m}$, $150-75 \mu \mathrm{m}, 75-53 \mu \mathrm{m}$ and $<53 \mu \mathrm{m}$ was used to study biosorption of $\mathrm{Cr}(\mathrm{III})$. Maximum sorption (67.2\%) was observed (Fig.4) with $150-75 \mu \mathrm{m}$ sized biomass. Finer size particles were found to agglomerate and thus decreasing the sorption to $55.5 \%$ with $<53 \mu \mathrm{m}$ size biomass. The mixed size material $<150 \mu \mathrm{m}$ was however, most effective with $84 \%$ sorption (Figure 2).

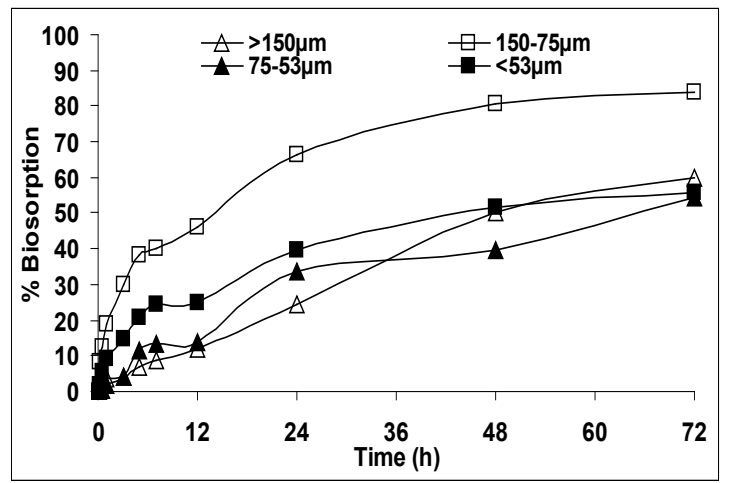

Figure 4. Effect of particle size on $\mathrm{Cr}(\mathrm{III})$ biosorption at $\mathrm{pH} 4.0,35^{\circ} \mathrm{C}$, $1 \%(\mathrm{w} / \mathrm{v})$ biomass

\subsection{Effect of the Sorbent Dose}

On varying the biomass from $0.1 \%-5.0 \%(\mathrm{w} / \mathrm{v})$, it was found that maximum biosorption occurred with $1 \%$ biomass as shown in Figure.5. The biosorption capacity increased as the concentration of the biomass increased from $0.1 \%$ to $1 \%$ as a result of availability of more binding sites. A minor decrease in the biosorption capacity was observed on increasing the biomass dose from $1 \%$ to $5 \%$ because of its agglomeration resulting in unavailability of binding sites for metal ions.

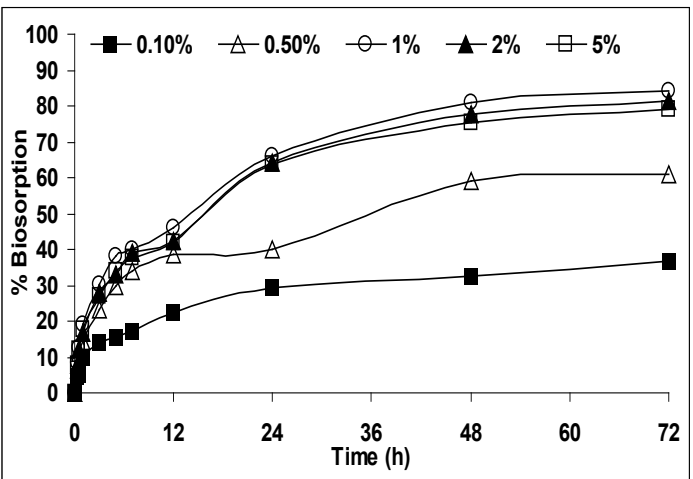

Figure 5. Effect of biosorbent dose on $\mathrm{Cr}(\mathrm{III})$ biosorption at $\mathrm{pH} 4.0,35^{\circ} \mathrm{C}$, biomass of $<150 \mu \mathrm{m}$ size

\subsection{Effect of Temperature}

The effect of temperature on the sorption of $\mathrm{Cr}$ (III) was also studied (Fig.6). The percentage biosorption increased with increase in temperature till $35^{\circ} \mathrm{C}$, thereafter it decreased because of greater degree of hydrolysis of the cell wall constituents[13] at $40^{\circ} \mathrm{C}$.

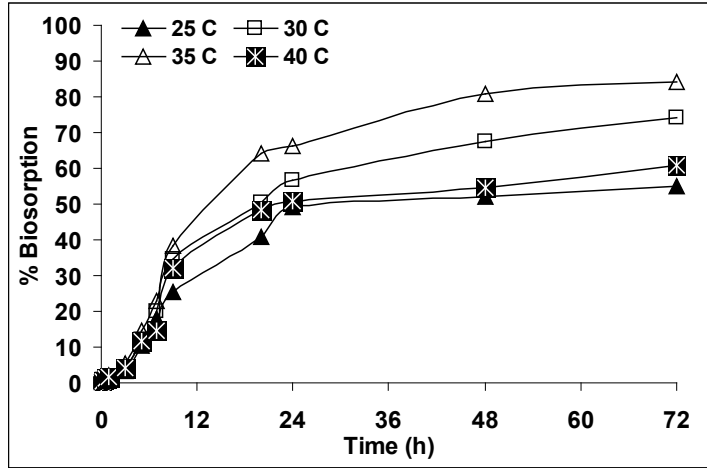

Figure 6. Effect of temperature on $\mathrm{Cr}(\mathrm{III})$ biosorption at $\mathrm{pH} 4.0,1 \% \mathrm{w} / \mathrm{v}$ biomass of $<150 \mu \mathrm{m}$.

The distribution coefficient $\left(\mathrm{K}_{\mathrm{D}}\right)$ is related to the Gibbs free energy change $\left(\Delta \mathrm{G}^{\circ}\right)$ as:

$$
\Delta \mathrm{G}^{\circ}=-\mathrm{RT} \ln \mathrm{K}_{\mathrm{D}}=\Delta \mathrm{H}^{\circ}-\mathrm{T} \Delta \mathrm{S}^{\circ}
$$

$$
\log \mathrm{K}_{\mathrm{D}}=\Delta \mathrm{S}^{\circ} / 2.303 \mathrm{R}-\Delta \mathrm{H}^{\circ} / 2.303 \mathrm{RT}
$$

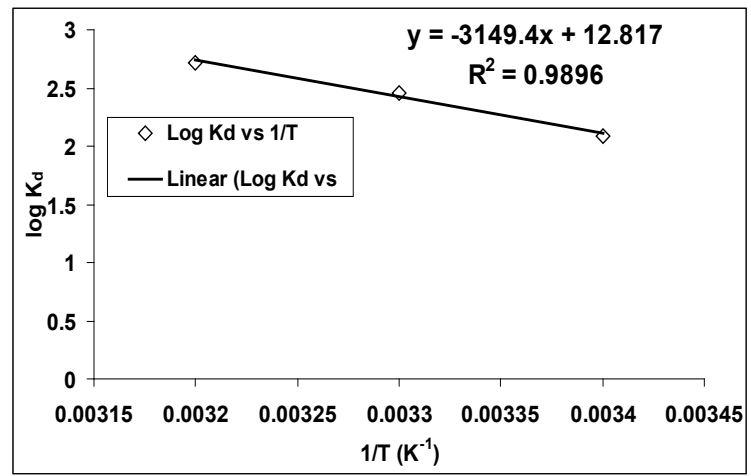

Figure 7. $\log \mathrm{K}_{\mathrm{d}}$ vs $1 / \mathrm{T}$ graphs for the biosorption of $100 \mathrm{ppm} \mathrm{Cr}$ (III) onto Penicillium at $\mathrm{pH} 4.0 ; m: 1.0 \mathrm{~g} ; t: 72 \mathrm{~h} ;$ size: $<150 \mu \mathrm{m}$ 
Table 2. Thermodynamic parameters for the biosorption of $100 \mathrm{ppm}$ $\mathrm{Cr}(\mathrm{III})$ on Penicillium $s p$

\begin{tabular}{|c|c|c|c|c|}
\hline $\begin{array}{c}\text { Temp } \\
(\mathrm{K})\end{array}$ & $\begin{array}{c}\Delta \mathrm{H}^{\circ} \\
(\mathrm{kJ} / \mathrm{mol})\end{array}$ & $\begin{array}{c}\Delta \mathrm{S}^{\circ} \\
(\mathrm{J} / \mathrm{K} \mathrm{mol})\end{array}$ & $\mathrm{R}^{2}$ & $\begin{array}{c}\Delta \mathrm{G}^{\circ} \\
(\mathrm{kJ} / \mathrm{mol})\end{array}$ \\
\hline 298 & \multirow{3}{*}{60.3} & \multirow{3}{*}{245.4} & \multirow{3}{*}{0.989} & -12.8 \\
\hline 303 & & & & -13.9 \\
\hline 308 & & & & -15.1 \\
\hline
\end{tabular}

The plot (Fig.7) of $\log \mathrm{K}_{\mathrm{D}}$ versus $1 / \mathrm{T}$ shows linearity and the calculated thermodynamic values are given in Table- 2 . $\Delta \mathrm{H}^{\circ}$ value was found to be $60.3 \mathrm{~kJ} / \mathrm{mol}$ indicating endothermic nature of $\mathrm{Cr}(\mathrm{III})$ chemisorption[14]. Negative values of $\Delta \mathrm{G}^{\circ}$ indicates the spontaneous nature of the reaction. The reaction is favored and getting easier as temperature rise from 25 to $35^{\circ} \mathrm{C}$.

\subsection{Intraparticle Diffusion}

The adsorption process on porous sorbents can be described by intraparticle diffusion; where in mass transfer within the sorbent particles may involve a short-range diffusion in both the fluid and adsorbed phases[14]. In the aqueous phase, pore surfaces are hydrated, resulting in both pore and surface diffusion of metals playing a role in the liquid phase adsorption on macroporous sorbents like fungal biomass. Intraparticle diffusion model is expressed as :

$$
q_{t}=k_{\mathrm{id}} t^{1 / 2}
$$

where $q_{t}$ is the amount of metal ions adsorbed at time $t$ and $k_{\text {id }}$ is the intraparticle diffusion rate constant. A plot of qt versus $\mathrm{t} 1 / 2$ is shown in Figure. 8.

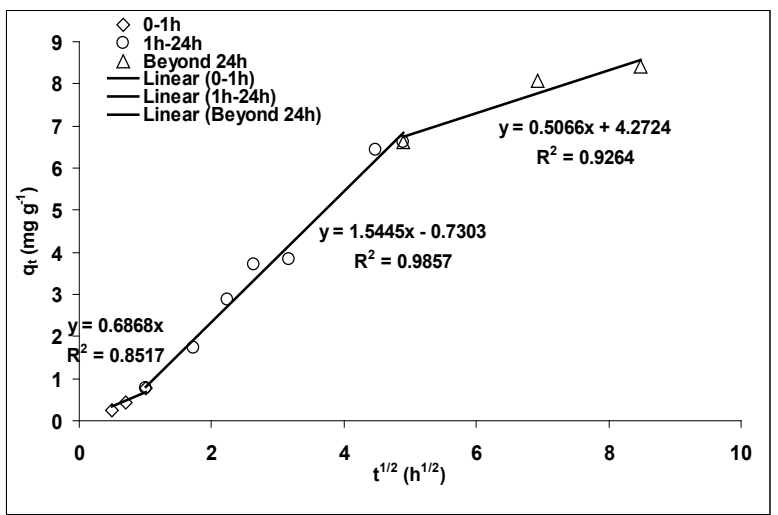

Figuer 8. Intraparticle diffusion plot for biosorption of 100ppm $\mathrm{Cr}$ (III) from MTE on $1 \%(\mathrm{w} / \mathrm{v})$ biomass of $<150 \mu \mathrm{m}$ size at $35^{\circ} \mathrm{C}$

With the biomass of $<150 \mu \mathrm{m}$ size, three slopes of the straight lines are seen (Fig.8): the first portion for 0-1h may be attributed to the external surface sorption due to the extremely low particle size as reported[14]. The second is the gradual sorption stage in 1-24h time, where the intraparticle diffusion may be the rate-controlling stage. The third and final equilibrium stage beyond $24 \mathrm{~h}$ corresponds to the slowing down of intraparticle diffusion because of low solute concentrations in the solution. When the adsorption has reached saturation at exterior surface, the $\mathrm{Cr}$ (III) ions might have entered in the pores within the biomass.
A comparison of intraparticle diffusion rate constants (mg/g.h) viz. $\left(\mathrm{k}_{\mathrm{i}} 1-0.68, \mathrm{k}_{\mathrm{i}} 2-1.54\right.$ and $\left.\mathrm{k}_{\mathrm{i}} 3-0.50\right)$ values and $\mathrm{R}^{2}$ values obtained from Fig. 8 follows the sequence:

$$
\mathrm{k}_{\mathrm{i}} 1<\mathrm{k}_{\mathrm{i}} 2>\mathrm{k}_{\mathrm{i}} 3
$$

\section{Conclusions}

1. Penicillium $s p$. isolated from the waste tanning solution shows promise to remove $\mathrm{Cr}$ (III) from model tanning effluent. Maximum $\mathrm{Cr}(\mathrm{III})$ sorption of $84 \%$ is achieved at $\mathrm{pH}$ $4.0,35^{\circ} \mathrm{C}$ temperature with $1 \%(\mathrm{w} / \mathrm{v})$ biomass of $<150 \mu \mathrm{m}$ size from a $\mathrm{Cr}(\mathrm{III})$ solution of $100 \mathrm{ppm}$.

2. At higher temperature of $40^{\circ} \mathrm{C}$ the sorption of $\mathrm{Cr}(\mathrm{III})$ decreases due to instability of the fungal structure. The increase in metal ion concentration beyond $100 \mathrm{ppm}$, decreases the biosorption efficiency. THE coarser particle size $(>150-75 \mu \mathrm{m})$ shows high metal uptake as compared to the fine size particles which gets agglomerated easily obstructing the binding sites of the pores. The mixed size material $<150 \mu \mathrm{m}$ removes $\mathrm{Cr}(\mathrm{III})$ most effectively(84\%) at $4.0 \mathrm{pH}$.

3. The $\mathrm{Cr}(\mathrm{III})$ sorption on the live biomass of Penicillium $s p$. is an endothermic process and is thermodynamically favourable with $\Delta \mathrm{G}^{\circ}$ value of $12.8-15.1 \mathrm{~kJ} / \mathrm{mol}$.

\section{ACKNOWLEDGEMENTS}

One of the authors (Divya) would like to acknowledge support of NML for offering DJRI. Analytical support by Dr.A.K.Upadhyay, ANCC, NML is acknowledged. Thanks are also due to the Director, NML for permission to publish the paper.

\section{REFERENCES}

[1] V.J.Sundar, J.R. Rao and C. Muralidharan: J. Cleaner Prod. 2001, vol.10, pp. 69-74.

[2] R. Ganesh and R. A. Ramanujam: Int. J. Environ. Eng. 2009, vol. 1(2), pp. 165-186.

[3] V.Suresh, M.Kanthimathi, P. Thanikaivelan, J. R. Rao and B. U. Nair: J. Cleaner Prod. 2001, vol. 9, pp. 483-491.

[4] Abhilash, K. D. Mehta, V. Kumar and B. D. Pandey: in proc. "National Seminar on Mineral Biotechnology(MB-2007)", Bhubaneswar, January 2007(eds. B. K. Mishra, L. B. Sukla and K. Srinivasa Rao) pp.190-201.

[5] A.L.Leitão: Int. J. Env. Public Health. 2009, vol. 6, pp. 1393-1417.

[6] A.I. Zouboulis, M.K. Loukidou and K.A. Matis: Proc. Biochem. 2004, vol.39, pp. 909-916.

[7] D. Park, Y.S. Yun and J.M. Park: Proc. Biochem, vol.40,pp. 2559-2565.

[8] B.Beverskog and I. Puigdomenech: Corrosion 
Science.1997,vol.39(1), pp.43-57.

[9] M. N. Sahmoune, K. Louhab and A. Boukhiar: Chemical Product and Proc. Modelling 2008. vol. 3(1), pp. 1-15.

[10] S. Srivastava and I. S. Thakur: Biores. Technol. 2006, vol. 97, pp. 1167-1173.

[11] M. Murugananthan, G. Bhaskar Raju and S. Prabhakar: Sep. and Purification. Technol.2004, vol.40, pp 69-75.
[12] S. Schiewer and B.Volesky: Environ. Microbe-Metal Interactions, ASM Press, Washington, DC, 2000, pp. 329-362.

[13] S.Nasseri, M.Mazaheri Ashadi, M.Noori Sepehr, Kh.Rostami, .M. Shariat and K.Nadafi, Pak. J. Biol. Sci. 2002, vol.5(10), pp.1056-1059.

[14] Nuri Unlu, Mustafa Ersoz, J.Hazard. Mat. 2006, vol. B136,pp. 272-280. 